\title{
EDUCAÇÃO DE JOVENS E ADULTOS
}

Coordenador: ILZA RODRIGUES JARDIM

Aulas para alunso de baixa renda que querem ingressar no Ensino Superior 